Copyright (C) 2021 The Author/s

This work is licensed under a CC-BY 3.0 License

Peer review method: Double-Blind

Accepted: August 20, 2021

Published: September 21, 2021

Review article

DOI: https://doi.org/10.47305/JLIA2137356af

\title{
EGYPT-TURKEY RELATIONS TOWARDS LIBYA: POLITICAL AND ECONOMIC DIMENSIONS
}

\author{
Abdulrahman Al-Fawwaz \\ Al-Balqa Applied University, Amman, Jordan \\ ORCID iD: https://orcid.org/0000-0002-2094-2922 \\ fawwaz77@yahoo.com
}

\begin{abstract}
Egypt and Turkey makeup about half of the whole population of the Middle East and are the two leading nations in the eastern Mediterranean, including Iran as a whole. Both countries are now recognized as the two most tremendous modern military forces in the Middle East. Besides, Cairo and Ankara are major Muslim centers: the Al-Azhar Mosque in Egypt is the largest Islamic University in the world and a significant feature of Egyptian soft power; the historical association between Turkey and the last Islamic Caliphate is viewed in the region with great nostalgia. Given these similarities, a deep rivalry between the two countries exists around the world, while Ankara and Cairo have increasingly prevented overt aggression or conflicts. After the Arab Spring, tensions have intensified and, in effect, impacts Libya, Sudan, and the Eastern Mediterranean region. Along with the increased risk of an overt war between the two nations, the rivalry between Turkey and Egypt also challenges the delicate security of the Middle East. It indicates that it needs an international mediator to answer this thorny problem.
\end{abstract}

Keywords: Turkey; Libya; Egypt; Political Dimensions; Economic Dimensions

\section{INTRODUCTION}

Following Gaddafi's removal in October 2011, there was an immediate leadership vacuum that led to extensive violence, a refugee crisis, and increased tribal conflicts, as well as economic instability and social welfare collapse. Libya is fractured, polarized, and insecure today. It is a failed state in many ways without a unified representative and lawful government capable of exercising authority or monopolizing the use of force. To establish a complete settlement between different factions in Libya, the country's political and security situation is extremely complex. Libya's political spectrum was split in two by the 2014 civil war: the UN-backed Government of National Accord (GNA) and its opposition in the country's eastern part. Khalifa Haftar, leader of the self-styled Libyan National Army (LNA) from the Eastern region, launched an offensive to seize Tripoli from the internationally recognized government. There have been more conflicts since Haftar took control of the capital. An important contributing element to Libya's 
political fragmentation and polarization has been the meddling of international powers. Political or regional interests of other countries have been a constant aspect of the postrevolutionary conflict. Recently, the Turkish approach to Libya has been mostly valuedriven. Turkish involvement in Libya's conflict has increased since Gaddafi's administration fell. An important backer of the GNA is Turkey.

The GNA's recent progress against Khalifa Haftar's so-called Libyan National Army (LNA) has changed the course of the Libyan civil war since June 2020 (Alimi et al. 2016). They and their international supporters have yet to come up with a persuasive diplomatic approach. Mistrust between Turkey and Egypt is a major hurdle to diplomatic progress. To reach a diplomatic agreement that can end Libya's civil war, both parties must be on board. A unilateral solution to Libya's problem is not an option for either country. It's no secret that both Ankara and Cairo (two major Muslim centers in Egypt) are at odds with one another.

While both Egypt and Turkey are aware of and recognize each other's interests and vulnerabilities in the Libya issue, none party fully understands or respects the others. Instead, they see the other's viewpoint as a hindrance to the realization of their essential national security and economic objectives. Turkish-Egyptian rifts make it possible for sabotage to take place (Alimi et al. 2016).

The Egyptian side wanted to offer a military response concerning the Libyan Civil War with the leadership position of a strong man. They felt they should usher in Haftar as the next Moammar Gaddafi from Libya with assistance from France, the United Arab Emirates, Saudi Arabia, Russia, and the USA (Parchami 2012). They intended to more conveniently smash the Islamist groups in Libya and establish a down-grading authority through a general with secular credentials. But the Haftar paradigm in Libya crashed over the last few weeks, and Haftar was not an asset but a liability for the Egyptian side of the region. Haftar was not adequately powerful, wise, or capable to peacefully lead Libya. He was diminished in reputation by his most recent actions against the denials of Libya's diplomatic accord, attacks on GNA-controlled civilian installations, and war crimes. Haftar's alleged Medkhali Salafis are not moderate actors and are funded by Saudi Arabia and the United Arab Emirates (UAE).

Parchami (2012) asserts that the Medkhali Salafis committed horrific human rights abuses in Tarhuna and in other areas where they had a significant impact. Haftar's partnership with the Medkhalis runs counter to the secular model that is often used to justify him. It is not appropriate for Egypt to sponsor Warlord Haftar with support and motivation from the UAE and other allies. Haftar is a warlord and terrorist who committed war crimes in Libya. In an international inquiry, his foreign partners will also be investigated (Chase 2016). A mutual agreement between Egypt and Turkey would protect the interests of both countries in the East Mediterranean. The deal with Greece and the Greek Cypriot government is not aligned with Egypt's Eastern Mediterranean 
long-term interests. Similar to that between Libya and Turkey, maritime demarcation arrangements between Turkey and Egypt will support the interests of both parties.

Turkey and Egypt can have some political differences, and leadership differences may have adverse effects on relations, but productive discussion on the lower level is not stopped. The geographical ground and the profound cultural and historical ties between the two countries are not more important than ideological differences. The long-term interests of Egypt will bring even greater Turkish-Egyptian partnership than Cairo's current alliance with Abu Dhabi and Riyadh (Beck n.d.). The aspirations of Saudi and Emirates lead to chaos in Yemen. Specifically, Saudi Arabia, in particular, was an unpleasant experience. Disagreements and competition between Turkey and Egypt raise the susceptibility of Libya to international intervention. Both countries should break up their ties and progress in the areas of common interest. Turkey and Egypt have continued to continue to strengthen their economic relations amid geopolitical tensions (Alimi et al. 2016). This enduring friendship between the two countries avoided further degradation in the trading field. There are also substantial business and trade opportunities with Egypt. There are no gaps between the two countries on social and cultural grounds. Egypt is worried about Turkey's Muslim Fraternity ties, but it does not have any purpose, through the Muslim Brotherhood (MB), to shape Egyptian domestic policy.

Now is the best time for Turkey and Egypt to split and move on, at least in the Libyan view. Libya could be more a bridge than a hurdle to improving Ankara-Cairo relations (Parchami 2012). The Libyan players themselves determine the finishing line in the civil war in Libya, but the mutual understanding between Turkey and Egypt will play a crucial part in building diplomacy.

\section{PROBLEM STATEMENT}

Egypt's regime, under President Abdel Fattah Al-Sisi, declared the Muslim Brotherhood a terrorist group that has taken dozens of its members to prison and selfexile in Turkey, Qatar, and Western Europe, following the 2013 ousting of Egyptian Mohamed Morsi, backed by a Muslim Brotherhood. After the crackdown, the expelled members also had an impact on Egypt. The new Egyptian administration itself is of considerable concern. Egypt's support of the GNA, and in particular, many influential persons has been firmly impelled by the Libyan branch of the MB and the LNA. President Al-Sisi expressed fear that MB voices in the GNA are a significant danger to national security in Egypt as the MB may use Libya's proximity to Egypt to conduct resistance campaigns around the Egyptian region. The GNA's new president Khaled AlMashiri said that his presidency was a significant concern. The LNA support from Egypt has led to a proxy war with Turkey that supports GNA through military consultants, troops, intelligence, and air support. It is also possible to trace this proxy war back to the 
opposition of Turkey's President Erdogan to the ouster of former President Morsi and his government. Turkey has publicly supported President el-Sissi's rule, thus improving the once warm ties between both nations. Turkey provides the influential MB leaders of Egypt with a haven. Egypt has assisted with all kinds, including but not limited to, the LNA's preparation and the start of operations in western Egypt, especially at the beginning of the conflict. Cheap Libyan oil was also a significant source of funding for the LNA in Egypt. As the LNA governs eastern Libya's oil-rich fields, it has become clear that Egypt has provided oil at a reduced pace in return for funding from the LNA. In this regard, this project sought to investigate the Egypt-Turkey relations in Libya by clearly analyzing the economic and political dimensions.

\section{LIMITATIONS}

Two main limitations limited the breadth and scale of this research. First, there is a general shortage of objective evidence from the previous studies related to this topic that might have helped to identify the research gap. Although there are many references, most do not have the Egyptian perspective and are restricted to a specific period or event. Finally, the revolution's complexity makes many aspiring authors and academics hesitant for reputation reasons to write on the issue. All these factors generate confusion and ambiguity in science in the preparation of solid materials and draw conclusions based on stringent experimental processes.

\section{DELIMITATIONS}

Three delimitations are applicable in addition to the limitations set out in the previous paragraphs. First of all, the study is unclassified. Secondly, the study will concentrate mainly on the EAF's role in the revolution. It will offer comprehensive insights into the transitional political structure by paying particular emphasis to the Muslim Brotherhood. Finally, the study gives a philosophical view. This perspective includes the thoughts of the author and does not reflect the official policy or plan of the Egyptian government or the Entity Armed Forces (EAF).

\section{METHODOLOGY}

The majority of the study technique is based on reading and analyzing the Turkish foreign policy process in the Middle East through an examination of a group of options, which is known as 'forecasting' or 'scenario analysis', as well as other methods of analysis. The scenario analysis is the most important method of predicting the future; nevertheless, this research does not present a single image of expectations or scenarios but rather presents many dynamic choices for the future of Turkish and Egyptian foreign 
policy in the next years. Consequently, a descriptive analysis of Turkish and Egyptian foreign policy, which is based on the idea of shared interest, can be used to determine the range of probable outcomes for any scenario under consideration.

The study of each scenario may be utilized for 'extrapolation of the past', which means that it will rely on historical data or information and conclude that it will be used to foretell the future. In addition, the research attempts to examine all of the prospective improvements in Turkish and Egyptian foreign policy that may be made in international relations. In the end, the scenario analysis has often authorized several scenarios through 'scenario analysis', which illustrates the potential repercussions in the future and has concluded the most likely scenario.

\section{THEORETICAL REVIEW}

\section{The Roots of the Libyan Crisis}

Libya had entirely different conditions in 2011 from Tunisia and Egypt. While the Libyan people, along with their excellent economic success, were ruled by an autocratic leadership, the bulk of the country had a relatively small population. The oil and gas industry has been able to absorb the majority of the country's qualified staff, which allows the rest to profit. A structure of allegiance developed over the years by alliances, nepotism, and money ensured tight political and security restrictions allowed President Muammar Gaddafi to retain power for an extraordinarily long time (Davutoglu 2013).

In the 1980s and 1990s, Gaddafi avoided battles with the United States and slowly established relations with the West and in Congo. In Libya, in 2011, there were no major clandestine resistance movements as the mainstream conflict was limited to a few people in the diaspora (Parchami 2012). Nobody predicted a Benghazi uprising or revolt in 2011 when Libya was considered to be one of the region's most prosperous nations. The outbreak of abuse in Cyrenaica's cities has shaken most of the countries of Europe, and that's why they have sent vague and misleading tweets.

Even Gaddafi was stunned and puzzled at the beginning of the 2000s; he was accepted as a victorious head of state, venerated by Europeans and supported by the US (Mezran 2012). Nevertheless, it soon became apparent that something different from merely revolting and more nuanced than mere local insubordination was occurring in the eastern territory of Cyrenaica. At the beginning of the coordinated action sequence, the presence of a vast volume of guns and ammunition and appearance at the ground level of a range of objectives showed the appearance of a strategy, inconsistent with a little upheaval. Another central element is the swift responses of some European governments, especially those of France and Britain, which almost universally embraced anti-government positions. 
Massive worldwide media reporting started transmitting an account of the Libyan situation, primarily based on the concept of brutal government response to a nonviolent public rebellion. The primary source of this report is the Qatari-based Al-Jazeera news network that has pioneered the systematization of photos of violence, chaos, anger, and death, persuading Europeans of Gaddafi's genocide to ensure his continued influence and rights (Al-Jazeera 2011). Many of the news reports that were shared regularly with western families explain how Gaddafi's air force targeted populated cities indiscriminately, killing thousands of civilian victims. The story was that it needed to be halted at all costs with the help of the international community (Krauss 2011).

A hesitant NATO and much more hesitant the US then embarked on a brief but comprehensive campaign directed at Libya's governmental properties on the ground, killed the local air force, prevented Benghazi from becoming loyalist. Gaddafi's defenses rapidly were damaged by the bombing, finally leaving the capital, a refuge in Sirte, his born place, and his tribal origins (Mezran 2014). Gaddafi finally was assassinated when he moved from one position to another quickly and refused to surrender to an opponent he didn't even know (Shanker and Schmitt 2011).

\section{Egypt-Turkey Relations}

Egypt's effort to form a national defense alliance against Turkey was heavily stressed in recent media reports. This relation is the latest episode of strained relations between both countries, which have been experiencing hostile ties since summer 2013, following General Abdel-Fattah Al-Sisi's military coup d'état, which has ousted late Mohamed Morsi from control. To establish the so-called 'defense coalition' that would be against Turkish involvement in the country, Abbas Kamel, Egypt's head of intelligence, has met with his counterparts in northern African countries. Egyptian and Libyan reports also confirm that "Egypt has formed an army commando force with Libyan activists to avoid Turkish ships from supplying assistance for Tripoli's internationally recognized government" (Alessia 2021; Omar 2014). These diplomatic and military tensions between Egypt and Turkey have many consequences for the Middle East and North Africa's peace and defense. Egypt's relations with Turkey have deteriorated considerably since the Egyptian coup in 2013. Turkish President Erdogan condemned and took over Morsi's followers, especially the Muslim Brotherhood, for the ousting of President Morsi. President Sisi, on his part, considers Turkey as a regional enemy and does not acknowledge its growing position and influence, especially in Libya and the Eastern Mediterranean. In the run-up to 2013, Turkey and Egypt had good and increasing ties, particularly in the aftermath of the Egyptian uprising in 2011 when their economic and geostrategic relationship was reinforced in both countries. Turkey interacted with the January 2011 Cairo - and the Arab Spring in general - revolt as a means of increasing its control in the region. It tried to create an alliance with new 
powers in Egypt, Morocco, Tunisia, and elsewhere, primarily with Islamists, in a geostrategic way that contradicted Ankara in the regional status quo.

The Turkish-Egyptian relations started to get worse after the breakdown of Egypt's transformation and the re-emergence there of the so-called 'deep state'. President Erdogan became very critical of the post-coup regime and endorsed the anticoup demonstrations led by the Muslim Brotherhood after the Rabaa massacre of 2013, which involved the killing of hundreds of peaceful protestors by Egyptian police. Egypt recalled the ambassador to Turkey in August 2013, not unexpectedly. A couple of months later, the Turkish ambassador to the world was expulsed from Cairo, and President Erdogan responded angrily, saying that "he would never honor those who come to power by military coups" (Christopher 2016).

\section{THE GEOPOLITICAL INCENTIVE}

Turkey has a significant regional presence in its geographical location, one which has traditionally enabled the growth of the Ottoman Empire. It is a predominantly Eurasian country in the Middle East and the Caspian Basin, bordered by states of Europe, Asia, the Near East, and the Black Sea. The strategic role of Turkey makes itself a stable political, economic, and cultural force that can serve as an initiator in development, a global peace hub, and a facilitator for the incremental extension of democratic values.

Egypt, as well, played a crucial part in world affairs, with its geographically unique geopolitical location. Based in North Africa, across the Nile River, Egypt wants adequate diplomatic relations with a variety of countries on the international level, with a diverse position at the center of the African, Arabs, and Islamic spheres (Nasser 1952, 51) and its immense geographical, commercial, and cultural significance. Furthermore, its Sinai crossroads connect Africa to Asia. Egypt is like "the center of the world, the great highway of nations", as defined by Alfred Milner (1899) - Under-Secretary of Finance from 1869-1892, and many foreign economies depend on it to conduct an export trade (Milner 1899).

\section{Ideological Animosity or Geostrategic Rivalry?}

Several factors, such as geography, culture, economy, history, natural capital, economic growth, and special interests, typically direct and influence foreign policy. This animosity is a mixture of all these considerations in the case of Turkey and Egypt (Cafiero and Wagner 2019). Both countries have a long past heritage, national identity, geostrategic value, and sincere ambition for global influence and are regarded as central players in the Middle East. Over the past couple of decades, Turkey's foreign policy has changed its emphasis from Europe and the Middle East, notably after it failed to join the European Union by engaging in its long-standing relationship with the region. 
Since the Arab Spring, however, the geographical position of Turkey has created fears and doubts among Arab authoritarian regimes, which, despite Erdogan's support for Arab Islamists, have begun to view Ankara as a strategic and ideological challenge to them. Such anxieties worsened as Turkey backed the Muslim Brotherhood after Morsi was ousted from office in 2013. While some observers prefer to look at his Islamist neighbors in terms of Erdogan's foreign policy against the Arab world, the battle between Turkey and its regional rivals, and especially Egypt in particular, is not to be overlooked nor underestimated. He was celebrated in the Arab streets and welcomed before the Arab Spring in the city's capital cities for his stance toward Israel and Iran, with his Islamic background in full recognition. Thus, political as well as strategic discrepancies may clarify the rivalry between Turkey and Egypt.

\section{Key Differences}

The relations between Egypt and Turkey are characterized by three main issues, especially after Sisi (Abdel Fattah Saeed Hussein Khalil el-Sisi), came to power as president of Egypt in 2014. Firstly, each country's geographical position and impact. Although Turkey views the Arab Middle East as the backyard in which power and control are wielded, Sisi thinks that the Turkish situation is a source of chaos and uncertainty. This inherent difference in their approach to foreign policy helps to identify and form the attitude of both countries to each other and the entire world.

Furthermore, President Sisi's rise to power was combined with a patriotic nationalist feeling regarding the ancient presence of his country in the Arab world. Despite its lack of economic and financial capabilities, it seeks to rebuild the role and image of Egypt.

The competition between Cairo and Ankara can be seen in two regional issues, at least: Libya and the East Mediterranean. In Libya, it was General Khalifa Haftar, a leading backer of the warlord, who has launched a military campaign against the official, UNrecognized National Accord Government (GNA) headquartered in Tripoli. Turkey's decision to send GNA military and logistical assistance escalated tensions with Egypt, which formally condemned the Turkish campaign and cautioned that "Turkey should have full responsibility for its effects", which would have a "significant impact on the security of the Mediterranean area" ( Aylin 2014).

The second issue involves the discovery of vast natural gas deposits in the Eastern Mediterranean region, adding fuel to the tensions that remain between Egypt and Turkey. In 2015, Egypt found massive natural gas reserves in Eastern Mediterranean waters. It started to use them to exploit Turkey economically and geostrategically, to establish relations with Turkey's antagonists in the Mediterranean, namely, Greece and Cyprus. Turkey has omitted Cyprus, Israel, Greece, Jordan, Palestinian, and Italy, as well as Egypt from this newly formed eastern Mediterranean gas forum (EMGF) in 2019. 
The EMGF is intended to increase the production of natural gas in the region and to establish a national energy market capable of exporting gas to Europe.

Turkey's exit from this forum was further proof of the region's increasing conflict, despite its geostrategic importance and interests in the Eastern Mediterranean. Egypt then vehemently opposed Turkey and told the United Nations Security Council to revoke it when it signed the security and maritime deal to the GNA. According to the agreement with the GNO of Libya, the naval warships in Turkey will exploit gas reserves in the eastern Mediterranean and ruin the ambitions of the EMGF.

The third issue that defines relations between Egypt and Turkey is the Egypt-Gulf Alliance, particularly between Saudi Arabia and the United Arab Emirates. Over the last couple of years, tensions have risen among Turkey, Saudi Arabia, Saudi Arabia, and the UAE. After a brief period of fiscal, military, and trade cooperation from 2011 to 2015, the relationship between both parties was characterized by growing mistrust and conflict.

Three key developments have intensified these strains: the aftermath of the Erdogan coup attempt in July 2016, the Qatar boycott starting in June 2017, and in October 2018, Saudi journalist Jamal Khashoggi was assassinated at the Saudi consulate in Istanbul. Indeed, some analysts refer to the role of Emirates in the attempt of coup d'état against Erdogan. However, Saudi Arabia, the UAE, Bahrain, and Egypt blockaded Qatar, which now hosts a Turkish military base, resulting in closer diplomatic ties with Qatar. The anti-Turkish feeling in the blocking countries has increased with this growth.

Finally, the assassination of the Khashoggi raised tensions toward Saudi Arabia, a significant friend and supporter of the Sisi regime. The three countries (Egypt, Saudi Arabia, and the UAE) reinforced the anti-Turkey Coalition; as this Coalition grows, the more intense the feelings of hostility spread towards Turkey. A significant role in the dispute with Sisi's regime is Turkish support for Egypt's political oppositions, especially the Muslim Brotherhood. Turkey offered the Muslim Brotherhood founders and leaders asylum after the coup in 2013.

Besides, it also allows free operation and transmission from Istanbul of the antiSisi media networks. Turkish actions threaten the government of Sisi, accusing Turkey of funding Egyptian extremism and instability. In fact, in reaction to the deal with the Libyan GNA in Turkey, Egyptian Parliamentarians last January called for the boycott of Turkish goods. At a fundamental level, Turkey must give up supporting the Brotherhood for the normalization of relations with Egypt. Egypt made it known when its Foreign Affairs Ministry declared in 2016 that it "is ready to normalize its relations with Turkey provided it recognized the validity of the overthrow of power from former President Mohamed Morsi" (Khalil Al-anani 2020). This was after Binali Yıldırım, former Prime Minister of Turkey, indicated that the "normalization of Egypt is probable" (Daily Sabah 2021). Ironically, their economic relations have evolved dramatically over the past couple of years, given the political tensions between Turkey and Egypt. According to the study of Egyptian-Turkish trade "Egypt and Turkey set the trade record of bilateral exports 
between the two countries in 2018: 3,05 billion dollars in Turkish exports to Egypt, up 29,4\% from 2017 and 2,19 billion dollars for Egyptian exports to Turkey, an increase of 9,68\% over the same period" (Rami 2019).

However, while some Egyptian parliamentarians have called for its annulment, the FTA concluded in 2005 remains unchanged. Nevertheless, despite the tough economic circumstances facing his country, Sisi is keen to preserve trade relations with Turkey.

\section{IMPLICATIONS FOR THE REGION}

Egypt and Turkey have enormous consequences for global security and stability as per their diplomatic split. Firstly, regional rivalries and more tensions have increased among the major players in the region. Turkey has immersed itself in nearly all of the Arab wars and hot areas, including Syria, Yemen, Libya, and the Gulf, over the past couple of years. Furthermore, these tensions of relations between Egypt and Turkey have redefined the rules of the game in a world that has formed new alliances and replaced the leading countries with the current confrontation map. While Egypt builds a strong partnership with Saudi Arabia and the UAE, Turkey has become Qatar's major strategically; after the 2017 blockade of Qatar, tensions within the Gulf have been steadily escalating. For the first time in the history of the Region, Israel was included in the alliance between Egypt, Saudi Arabia, and the United Arab States. Within this new alliance, Israel has helped to steer the flow of hostility against others, including Iran and Turkey. The world today is primarily separated into two groups: on the one hand, Egypt, Saudi Arabia, the United Arab Emirates, and Israel, and on the other, Turkey, Iran, and Qatar. Those two parties are disputing the area in different ways, and the tensions between the two sides are strengthened as the Coalition within each block strengthens.

Third, the troubled countries like Iraq, Libya, and Palestine have been intensified in Egypt-Turkey tensions. The growing position and involvement of Turkey in this area have generated problems with Arab governments who aim to counterbalance Turkey's presence at all costs in the region. To this end, the anti-Turkey powers in their countries provide massive military, economic and political assistance.

\section{RESULTS AND DISCUSSIONS}

\section{Results}

The study found out that the latest Turkish forces' military withdrawal from the western part of the country in Libya and Libya National Army (LNA) General Halifa Haftar has provided a new balance in the conflict. It may well be a moment of watching over Libya, mainly because of the so-called Cairo Declaration of June 6, 2020, Egypt, the United Arab Emirates, and Russia may reconsider their sponsorship of Haftar and make a potential agreement on Libya. Haftar is losing domestically and internationally - inside 
his powers to Egypt and the United Arab Emirates - to the extent, nobody is going to be betting on it again. Within this dynamic situation, neighboring Egypt, which strengthened Haftar since 2014, will play a significant new part in safeguarding its particular interests abroad and in Libya. Egypt's internal security and political integrity are significantly challenging to the situation in Libya. In the process of Cairo's strategic alignment and funding for the War of Haftar against the Tripoli's State, the National Agreement (GNA) became a significant geopolitical concern since 2013, supported by Turkey and Qatar. This dispute has been of great geopolitical significance for Cairo.

Egyptian President Abdel Fattah Al-Binali Yıldırım Sisi never concealed his support for a military solution to Haftar, a strongman of Libya's East, and the so-called LNA, following numerous efforts to appear as a mediator in the conflict - as was the case during the unsuccessful meeting held in Kairo in February 2017. In turn, the region is at the forefront of Egyptian interests, as the asymmetrical menace along the 1,115 kilometers long boundary between the two countries is steadily sought after to control and secure. Over the past few years, Egypt's efforts have taken several steps to secure the vulnerable borders and deter dangerous jihadi infiltration into Egypt from the East. This ideology is focused on guaranteeing the deployment of field armies in a counterterrorism mission and the start of a significant military campaign called Rad 24 in the West area close to the Siloam check-point. An emphasis has been put on the security of the North of Sinai. This strategic area has suffered numerous attacks by Wilayat Sinai associated with the Islamic State of Iraq and al-Sham (ISIS).

From Cairo's point of view, a potential spill of conflict could establish a volatile collision of interests with radicalized Muslim Brotherhood factions working both in Eastern Libya and the Western Desert of Egypt.

Recent events in Libya are threatening the unsustainability of Egypt's role. Cairo is based upon the relationship between the UAE and Saudi Arabia. Financial support to the Gulf is crucial for stabilization in Egypt, particularly in the course of a Covid-19 pandemic, which has overwhelmed Egypt's health care system; the number of confirmed cases has risen steadily, with more than 1000 infections a day since May 28, 2020 (Sudarsan 2020). Yet Cairo impatiently sees the inflexibility and low political acuity of the United Arab Emirates and Saudi Arabia in the Middle East as in the Libyan problem.

The rising strains with Turkey, which is now Tripoli's biggest ally, make the game more difficult in Libya. Such comparisons emerged from relations that were already deteriorating. Indeed, the two governments are on their way to a confrontation on a multitude of political and economic problems, such as Turkish sponsorship of secular Islam and geo-economic tensions in the Eastern Mediterranean. The establishment of an Eastern Mediterranean gas platform, which is firmly backed by Al-Sisi, threatens not only diminishing the value of Turkey's TANAP and Turkish Stream pipelines but also marginalizing Ankara from investment ventures for the Eastern Mediterranean gas exploitation. President Erdogan responded with his usual harshness to this threat. 
Turkey reached on November 27, 2019, and Understanding with the GNA, breaking international law on the delimitation of national waters on the boundary of its respective Commercial Exclusive Zones (EEZ) in the Eastern Mediterranean (Heinz 2021). Ankara agreed to support the struggle against Haftar forces and radicalized the position of Ankara and sparked diplomatic confrontations in Libya and led Ankara to react at all levels - not merely in the energy field (Heinz 2021).

The strained ties between Al-Sisi and Haftar are the most complicating issues in Egypt in Libya. Most recently, in Libya, Egypt, which perceives Libya as a theatre for economic and diplomatic reinforcement, is interested. The weak political and military leadership of Haftar might weaken Egyptian aspirations in this way. Interviews with many non-official Egyptian outlets reveal that Haftar is committed more to his external sponsor's resources than to his leadership skills. Haftar has also disclosed several other explanations for strained relations in his military failure, such as Watiya and Tarhuna and other civil war failures with the GNA. First, Egypt is not happy with the LNA's military operations in western Libya. Second, it is very annoyed with Haftar and its tactical flirtations with Gulf allies in Libyan, particularly in its inconclusive year of siege against Tripoli. Ultimately, the vague approach of Haftar is likely to undermine the reputation of Egypt in its geopolitical vicinity, as well as to jeopardize the hope of an Egyptian foreign policy that is capable of distancing itself from the hegemonies of Saudi-Emirates and Saudi Arabs in the Middle East. So, what do we expect from the dispute?

Russia's latest developments in Libya and multi-faceted Egyptian projects - such as Italy's so-called Cairo Declaration and multi-billion weapons - may contribute to the complexities of that. One could believe Moscow preferred to prevent further intervention in the dispute, but that it will not necessarily allow Haftar to be defeated (McGregor 2018). If the policy of the Kremlin is to take over the mediating power of the potential future negotiations with Turkey, Haftar can become a bargaining pawn outside the internal dynamics of Libya. Their repercussions will have international ramifications, maybe even the Syrian crisis, which, amid co-led diplomatic attempts, still sees Russia and Turkey on the other side.

This might sound like a warning bell to Haftar and her allies, advising them to consolidate their position in the East concerning possible talks with Turkey and the Tripoli administration. The Gulf monarchies, the most committed proponents of the Haftar up to now, should follow the line indicated by Moscow - not involved in pursuing a war that they do not consider as winners. Egypt may, therefore, benefit from the crisis in Haftar and, for the medium term at least, seek to find more trustworthy political alternatives. Besides, Egypt should still see sponsorship of Haftar as a simple short-term option, as appropriate substitutions are not possible. Around the same time, Haftar's assistance is a realistic means to control, from the Egyptian viewpoint to foreign policy, Turkish maritime, and defense assertiveness in Libya and the broader Mediterranean. 


\section{Discussion and Normalization}

Cooperation between Egypt and Turkey would provide the ability to improve its regional leadership role. Egypt will benefit from the political planning stage from Turkish economic policies aimed at making the budgetary policy more stable, monetary policy was more efficient, and the financial system more confident. Turkey and Egypt should use their roles to jointly establish a national security framework to counter the ongoing terrorist threat that afflicts the Libya crisis. The country will benefit and help restore peace by coordinated joint action through a comprehensive anti-terrorism policy partnership between military, intelligence, law enforcement, and the diplomatic fields.

The joint effort will include the capability of partners, the creation of skilled security forces; internal defense support; and the execution of special operations (Jones 2014). The transformation of Turkey was made possible through the political and economic reforms of the Justice and Development Party (AKP) that resulted in stability and credibility. Since 2002, the state has concentrated on increasing domestic capital spending, foreign direct investment, commerce, and trading partners through its economic, fiscal, and monetary policies (Tolga 2013). Within a more stable environment, both domestic and international business groups will better organize long-term market plans.

Turkey was slowly moved from conventional agriculture to industrial cultivation and more advanced manufacturing, rendering it the ninth largest country in the world, a significant trade partner for the EU, and a center of economic growth.

Turkey also took on a role in transportation from Caspian, Central Asia, the Atlantic, and the Eastern Mediterranean as a conduit and as a power bridge through vast amounts of hydrocarbon supplies to the European Union (Roberts 2004). Turkish aircraft is one of the most congested transit points of fuel in the world with several international and domestic pipelines in addition to the Bosporus and Dardanelles Straits, averaging 3 million barrels per day. Its central position as a transport center is expected to grow in the coming years, as $70 \%$ of the world's oil and natural gas reserves are located in the region (Tolga 2013).

Egypt, on the other hand, has considerable potential for expansion and is one of the most advanced and diversified economies in MENA (UNECA 2013). The Egyptian economy has resumed its operations in most industries, despite the domestic uprisings since the uprisings. The recent, but slowing, growth of 1,4\% between 2013 and 2014 (Trading Economics 2014) shows that. Attempts to improve economic growth by improved infrastructure, monetary and fiscal policies are being made continuously.

Dr. Ashraf El-Araby was announcing a comprehensive reform of investment and labor laws to promote foreign direct investment and to enable the setting up of Egyptian SMEs. 
In transit flows, Egypt's Suez Canal, completed in 1869, connects the Mediterranean Sea to the Indian Ocean, two main rivers directly, via the Red Sea (McGregor 2006). Egypt plays a vital role in world commerce and economic growth as a gatekeeper between Africa, Asia, and Europe. Today, some 8 percent of container ships worldwide bear containers, fewer than the Panama Channel, into the Suez Channel (Cole 2013). It is expected that this number will increase as the recently planned parallel link to the Canal is finished in 20158 (Farid 2014). More than 2 million barrels of oil are expected to flow through Egypt through the Canal or pipelines (Yazdani 2015). Turkish, French, and American importations of liquefied natural gas were obtained from Suez Canal by almost $25 \%$ in 2010 , making them a focal point on fuel price and trade stability (Cole 2013). Any future geopolitical disruption that could contribute to the closure of the Suez Canal in Egypt could thus have significant implications for foreign trade, oil supply, and prices. When the demonstrations first began in Egypt on January 25, 2011, for example, oil prices soared to their peak levels since 2008 (Schuman 2011).

\section{CONCLUSION}

The crisis in Libya has emerged as a result of a diverse and refined series of trends in which exogenous forces have greatly affected and guided local political activities. In the Euro-Mediterranean and the Inter-Arab divisions, a dual set of competing interests is found, with Italy and Turkey fighting France, with Turkey fighting Great Britain, and Qatar fighting the United Arab Emirates and Saudi Arabia on the one side. A war that was predominantly waged by non-Libyan forces, which ultimately prompted the fall of the central institutions in Libya and the formation of thousands of Local militias, hit Muammar Gaddafi's rule and which undoubtedly was not a paradigm of good governance and respect for human rights. The collapse of both local and exogenous aspirations led to the instability that allowed external forces to affect the Libyan civil war and made the situation rather complex and challenging to address.

Turkey and Egypt could benefit from having access to modern, less conventional markets and hence more significant interaction with the world economy. Ibrahim ElAraby, Vice-President of Cairo Chamber of Commerce, affected that "trade practices in Egypt are having an immediate effect and are a result of the trade levels in the Arab world. In the energy market, Turkey pursued more outlets to meet its rising energy demand because of the rapid social and economic changes. Sustainable development relies on the availability of energy supply and stability" (Omar 2014). The project to move natural gas from Egypt to Turkey through Syria and Jordan has included recent projects. This investment will lead to diversifying Turkish fuels and to improving Egypt as a transport point in the future. 


\section{REFERENCES}

1. Alimi, E. Y., Sela, A., \& Sznajder, M. (2016). Popular contention, regime, and transition: Arab revolts in a comparative global perspective. Oxford University Press.

2. Ashour, O. (2017). Between ISIS and failed states: The saga of Libyan Islamists. Washington, DC: Brookings Institution, Rethinking Political Islam Series.

3. Alessia Melcangi (2021). Egypt recalibrated its strategy in Libya because of Turkey, Retrieved from https://www.atlanticcouncil.org/blogs/menasource/egyptrecalibrated-its-strategy-in-libya-because-of-turkey/

4. Aylin Gürzel (2014). Turkey's role as a regional and global player and its power capacity: Turkey's engagement with other emerging states, https://doi.org/10.1590/1678-987314225007

5. Bassiouni, M. (2014). Will Egypt's military intervention secure the Libyan Border? (Trans. Cuyler, Z.). Al-Monitor. Retrieved from www.almonitor.com/pulse/security/2014/08/Egypt-Libya border-chaos-militaryintervention.html

6. Beck, M. (n.d.). The Arab Spring as a challenge to political science. The International Politics of the Arab Spring. https://doi.org/10.1057/9781137481726.0004

7. C. (2016). Who is Khalifa Haftar, Libya's divisive general? Newsweek, July 22.

8. Cafiero, G., \& Wagner, D. (2019). How the Gulf Arab rivalry tore Libya apart. The National Interest, December 11.

9. Carnegie-MEC. (2017). Turkey's Relations with a Changing Arab World. Carnegie Middle East Center. Retrieved from, https://carnegie-mec.org/2017/05/03/turkeys-relations-with\%20changing-Arab-world/ayti

10. Chase, A. T. (2016). Routledge handbook on human rights and the Middle East and North Africa. Taylor \& Francis.

11. Christopher. B. (2016). After a decade in power, Turkey's ruler presides over a new form of democracy that the west neither likes nor understands: an authoritarian regime that exalts the will of the majority. Retrieved from https://www.theguardian.com/world/2016/aug/30/welcome-to-demokrasi-howerdogan-got-more-popular-than-ever

12. Crisis Group. (2019). Addressing the Rise of Libya's Madkhali-Salar is the Middle East and North Africa. Report No: 200. Retrieved from: https://d2071andvipOwj.cloudfront.net/200-libyas-madkhali-sala $\mathrm{is.pdf}$

13. Crisis in Libya: Who is to blame? (2016, October 21). Breaking News, World News, and Video from Al Jazeera.

https://www.aljazeera.com/programmes/upfront/2016/10/crisis-libya-blame$\underline{161021112850279 . h t m l}$ 
14. Daily Sabah (2021). Egypt hails Turkey's move to normalize diplomatic relations. Retrieved from https://www.dailysabah.com/politics/diplomacy/egypt-hailsturkeys-move-to-normalize-diplomatic-relations

15. Davutoglu, A. (2013). Turkey's New Foreign Policy Vision.ll Insight Turkey, 10, (1).

16. Efegil, E. (2016). "Foreign Policy-Making in Turkey: A Legal Perspective." Turkish Studies, 2, (1).

17. Egypt Independent (2012). The Egyptian government offers Turkey new investment opportunities. Egypt Independent. Retrieved from www.egyptindependent.com//news/Egypt-government-offers-turkey-newinvestment-opportunities

18. Egypt-Turkey strained relations: Implications for regional security. (n.d.). Arab Center Washington DC | Independent and Nonpartisan Research Organization. https://arabcenterdc.org/policy analyses/egypt-turkey-strainedrelations-implications-for-regional-security/

19. Heinz-Jürgen (2021). Troubled Water in the Eastern Mediterranean. Turkey Challenges Greece and Cyprus Regarding Energy Resources. Comparative Southeast European Studies. https://doi.org/10.1515/soeu-2021-2006

20. Geostrategic dimensions of Libya's Civil War - Africa center. (2020, July 24). Africa Center for Strategic Studies. https://africacenter.org/publication/geostrategicdimensions-libya-civil-war/

21. Khalil Al-anani (2020). Egypt-Turkey Strained Relations: Implications for Regional Security. Retrieved from: https://arabcenterdc.org/resource/egypt-turkeystrained-relations-implications-for-regional-security/

22. Libya and Egypt. (2016). Great Desert Explorers, 189 238. https://doi.org/10.2307/j.ctvk8w11t.13

23. Libya Crude Oil Production data. (2019). U.S. Energy Information Administration. Retrieved from: https://wwweia.gov/opendata/qb.php?category $=1039874 \&$ sdid=STEO.COPR LY.A

24. Libya is trapped between a strategy of chaos and the specter of a new dictatorship. (2020, February 11). The Africa Report.com. Retrieved from https://www.theafricareport.com/22540/libya-trapped-between-a-strategy-ofchaos-and-the-spectre-of-a-new-dictatorship/

25. McGregor, A. J. (2018). A military history of modern Egypt: from the Ottoman Conquest to the Ramadan War. Library of Congress.

26. Müftüler-Bac, M. (1997). Turkey's relations with a changing Europe. Manchester University Press.

27. Omar Sheira (2014), Turkey-Egypt Relations: Incentives to Normalize, GPoT PB No. 40. Global Political Trends Center Istanbul, Turkey. 
28. Ozkan, M. (2013). Does "rising power" mean "rising donor"? Turkey's development aid in Africa. Africa Review, 5(2), 139147. https://doi.org/10.1080/09744053.2013.855358

29. Ozkan, M. (2016). Turkey's political-economic engagement with Africa. Emerging Powers in Africa, 217-231. https://doi.org/10.1007/978-3-319-40736-4 11

30. Parchami, A. (2012). The 'Arab Spring': The view from Tehran. Contemporary Politics, 18(1), 35-52. https://doi.org/10.1080/13569775.2012.651272

31. Rami Galal (2019). Egyptian-Turkish trade: A love-hate relationship. Retrieved from https://www.al-monitor.com/originals/2019/06/egypt-turkey-free-tradeagreement-politics-economy-tension.html

32. Sudarsan Raghavan.The Washington Post (2020). Egypt thought it dodged the worst of the pandemic. But now hospitals are being overwhelmed. The Washington Post. https://www.washingtonpost.com/world/middle east/egyptthought-it-dodged-the-worst-of-the-pandemic-but-now-hospitals-are-beingoverwhelmed/2020/06/16/36397b8e-af2c-11ea-98b5-279a6479a1e4_story.html

33. Tellidis, I., \& Toros, H. (2016). Terrorism: Bridging the gap with peace and conflict studies: Investigating the crossroad. Routledge.

34. Tolga Demiryol (2013). The Geopolitics of Energy Cooperation between Turkey and the European Union. No 367,109 - 134. DOI 10.3917/eufor.367.0109

35. Wheeler, A. T. (2011). Ankara to Africa: Turkey's outreach since 2005. South African Journal of International Affairs, 18(1), 43-

62. https://doi.org/10.1080/10220461.2011.564426

36. Yazdani, I. (2015). Muslim Brotherhood debates the Turkey model. Hürriyet Daily News. Retrieved from

http://www.hurriyetdailynews.com/default.aspx?pageid $=438 \& \mathrm{n}=$ muslimbrotherh ood-debates-turkeymodel-2011-0914 